\title{
Factors Predicting Individuals' Behavioural Intentions for Choosing Cultural Tourism: A Structural Model
}

\author{
Silvia Platania ${ }^{1}$ (D), Kyle Maurice Woosnam ${ }^{2,3, *}$ and Manuel Alector Ribeiro ${ }^{3,4,5}$ \\ 1 Department of Educational Science, Section of Psychology, University of Catania, 95131 Catania, Italy; \\ splatani@unict.it \\ 2 Parks, Recreation and Tourism Management Program, Warnell School of Forestry and Natural Resources, \\ University of Georgia, Athens, GA 30602, USA \\ 3 School of Tourism and Hospitality Management, University of Johannesburg, \\ Johannesburg 2006, South Africa; m.ribeiro@surrey.ac.uk \\ 4 School of Hospitality and Tourism Management, University of Surrey, Guildford GU2 7XH, UK \\ 5 Research Centre for Tourism, Sustainability and Well-Being (CinTurs), Faculty of Economics, Campus de \\ Gambelas, University of Algarve, 8005 Faro, Portugal \\ * Correspondence: woosnam@uga.edu; Tel.: +1-864-653-0167
}

Citation: Platania, S.;

Woosnam, K.M.; Ribeiro, M.A.

Factors Predicting Individuals'

Behavioural Intentions for Choosing Cultural Tourism: A Structural Model. Sustainability 2021, 13, 10347. https:/ / doi.org/10.3390/su131810347

Academic Editors: Lucia Marchegiani, Mark Bonn and Enrico Cori

Received: 7 July 2021

Accepted: 14 September 2021

Published: 16 September 2021

Publisher's Note: MDPI stays neutral with regard to jurisdictional claims in published maps and institutional affiliations.

Copyright: (c) 2021 by the authors. Licensee MDPI, Basel, Switzerland. This article is an open access article distributed under the terms and conditions of the Creative Commons Attribution (CC BY) license (https:// creativecommons.org/licenses/by/ $4.0 /)$.

\begin{abstract}
Drawing from the theory of self-regulation and a model of goal-directed behaviour, this study examines the determinants (i.e., attitudes, subjective norms, perceived behavioural control, desire, negative WOM coping strategies, and avoidance coping strategies) of visitors' intentions to engage in cultural tourism within Sicily. Based on a sample of 469 visitors, the results revealed that 12 of the 14 proposed hypothesised direct effects were significant in explaining behavioural intentions to choose a cultural holiday. As for indirect effects, negative WOM coping strategies served as a more salient mediator in the model, as opposed to avoidance coping strategies.
\end{abstract}

Keywords: cultural tourism; negative word-of-mouth (WOM); avoidance; self-regulation theory; self-directed behaviour; mediation

\section{Introduction}

Cultural tourism research has steadily increased over the last few decades, as more individuals intentionally seek out the cultural attributes of destinations they visit. This is especially true among visitors who strongly identify with particular cultures [1]. Cultural tourism, in a basic sense, encompasses travelling to destinations and engaging in activities that provide opportunities for experiencing others' diverse ways of life, thereby gaining a first-hand understanding of local customs, traditions, intellectual ideas, the physical environment, and those places of architectural, historical, archaeological or other cultural significance [2,3]. Moreover, the expanding notion of tourists' cultural consumption makes the definition of cultural tourism increasingly elusive [4]. According to Barbieri and Mahoney [5], a contemporary understanding of cultural tourism includes not only tangible aspects, but also intangible cultural elements, such as an "appreciation of a way of life for particular cultures" [6] (p. 972). Central to cultural tourism is the idea that "individuals seek to gain an understanding or appreciation of the nature of the place being visited" [7] (p. 204). In recent years, especially in Europe (but generally throughout the world), cultural tourism has been considered an important economic driver for many local destinations, regions, and countries [8-12]. As such, the diversity of cultural resources and the ability of the site to meet the needs of tourists through its hospitality are considered highly important "pull" factors. In helping to meet the growing needs of specialized travellers, cultural tourism can be considered a thriving alternative form of sustainable tourism, largely in response to mass tourism pursuits [13].

Some of the most salient driving factors behind destination choice focus on perceptions of the place under consideration [14]. These perceptions are often intertwined with visitors' 
values and motivations [15], the latter of which are often considered either push factors (e.g., self-expression, self-development, relaxation, and prestige internally motivating a person to travel) or pull factors (e.g., external to the individual and illustrated in the attributes of a destination) [16]. Considering the various studies connecting the effects of self-concept with destination image (self-congruity), and destination with attributes and a tourist's ideal expectations (functional congruity), on travel behaviour, destination selection is largely precipitated by the connection tourists make between expectations and the potential advantages of visiting [17-22]. Furthermore, tourists develop strategies of self-regulating emotions as they consider particular holidays; emotions that can be either positive (in attracting a tourist to the destination) or negative (by discouraging a tourist from selecting the destination) [23]. Moreover, "self-regulation and cognitive control models agree in their characterization of emotion regulation as an effortful top-down control process that is guided by goals" [24] (p. 13).

The purpose of this work is to investigate the role that emotions (i.e., motivations, expectations and attitudes) may play in predicting tourists' intentions to engage in cultural tourism. Furthermore, we are keen to investigate the role that coping factors (i.e., avoidance and negative word-of-mouth or WOM) may play in mediating the relationship between emotions and intentions to engage in cultural tourism holidays. The consideration of this mediation surrounds the growing interest among researchers in connecting tourists' emotions with factors of attraction to and repulsion from destinations, and how this relationship has significant implications for tourists' well-being and quality of life. The results of this study will contribute to the burgeoning research on cultural tourism, especially in helping to pave the way for future research that models potential tourists' decision-making in selecting cultural tourism holidays. This work is also significant in determining how destination marketing organizations can best position themselves to account for potential visitors' emotions when selecting their destination over others.

The structure of this paper will begin with a review of the pertinent literature concerning cultural tourism, self-regulation theory, travellers' motivations and behavioural intentions, and coping strategies and goal-directed behavioural intentions. This review will serve to provide support for the formulated direct and indirect effects hypotheses in the proposed theoretical model. Following this, research methods are discussed. Results from the confirmatory factor analysis and structural equation model are then provided, which will address each of the model hypotheses. Finally, the paper concludes with a discussion of implications (theoretical and practical in nature), limitations, and future research opportunities.

\section{Literature Review, Theoretical Framework and Hypotheses Development}

\subsection{Cultural Tourism}

Considering cultural tourism as a form of sustainable tourism, Tyrrell, Paris, and Biaett [25] contend that a central focus of sustainable tourism is ensuring that the "triple bottom line" (TBL) of the community is realized, such that social-cultural resources are promoted and minimally impacted, while the environment is minimally impacted and the economy is stimulated. This social-cultural leg of the "TBL stool" is at times, however, not the central focus within sustainable tourism planning and research [26,27]. Of course, considering the demand side of tourism is also crucial for sustainable tourism. As such, providing a pleasing tourist experience is crucial to the long-term success of a destination when planning and managing for sustainable tourism [28].

Although travellers' experiences have received significant research attention, various segments likely perceive such experiences differently based on their motivations. Emotional experiences act as antecedents of the overall perceived image of the destination and contribute to satisfaction. As such, emotions influence various stages of the tourist's experience [29-32]. At the pre-travel stage, emotions play a fundamental role in tourists' motivations [33,34] and destination choice processes [35]. At the post-travel stage, integrating the effects of emotions on post-consumption behaviours is an important development 
in consumer and tourism research [33,36-38], especially as it relates to behavioural change and intentions to revisit. Based on the literature, it is evident that emotions precede tourist choice, and consequent motivations induce individuals to choose not only a particular place to visit, but also the type of holiday to undertake. As such, the aim of this research is to investigate emotional antecedents and motivations contributing to tourists' behavioural intentions in terms of selecting cultural tourism holidays.

\subsection{Self-Regulation as a Determinant of Decision Making in Tourism Choice}

To understand motives, it is best to start with identifying individuals' most salient goals. Goals are defined as the "internal representation of desire states, where states are broadly construed as outcomes, events, or processes" [39] (p. 338). To better explain goal striving, Bagozzi, Baumgartner, and Pieters [40] introduced anticipated emotions as predictors of volitions to act. The authors argued that people, when considering whether to act in goal-directed situations, consider the emotional consequences of either achieving or not achieving a sought-after goal [40]. According to Bagozzi [41], attitudes do not necessarily result in intentions to act, because motivations must be acknowledged.

The theory of self-regulation or model goal-directed behaviour (MGB) is based on two well-received social psychological theories: (1) the theory of reasoned action (TRA), including attitudes, subjective norms and behavioural intentions [42-44], and (2) the theory of planned behaviour (TPB), including perceived behavioural control, which increases the predictive power of TRA $[42,45,46]$. The MGB expands the TPB [47] by including desire as an essential mediator and incorporating the effects of anticipated emotions as a form of forward-looking counter-factual thinking about goals [48]. The theory of selfregulation is one framework to consider in explaining this idea. Self-regulation is typically considered a complex, universal human ability that structures goal-directed behaviour and increases the likelihood of fulfilling a variety of individual needs. This and individual differences in self-regulation underline the necessity to investigate its components, its developmental conditions, and its activation in different contexts. Given this, investigators have consistently highlighted that standards for self-regulation, and related strategies differ among individuals from distinctive cultural backgrounds.

One's motivational commitment lies in the greatness of the desire to act. Desires (as distinct from attitudes and beliefs) are thought to be very important in the genesis of human actions and are argued to contribute to an individual's behavioural intentions. For example, Bagozzi and Dholakia [49] indicate that an indicator of self-regulated goal-setting is choosing a level of difficulty that will maximize achievement (a task that is neither too easy nor too difficult). An indicator of effective self-regulation is when an undesirable dominant behaviour is intentionally inhibited.

The ability to self-regulate (e.g., by effortful control) is complemented by motivations and intentions to self-regulate in line with others' expectations. These expectations, in turn, are influenced by cultural values. Therefore, self-regulation differs with respect to the respective dominant cultural values and the related cultural model of agency (i.e., attitudes $\rightarrow$ desires $\rightarrow$ intentions), as modelled by Bagozzi's [41] conative self-regulation of the attitude-intention relationship.

A missing element in attitudinal theory is the mechanism that transforms assessments into intent. Lazarus [50] argues that the processes of appraising internal and situational conditions lead to emotional responses; these in turn result in coping activities (i.e., appraisal $\rightarrow$ emotional responses $\rightarrow$ coping). In the presence of a particular emotion, two coping responses are possible. The first concerns both past and present reactions. One's purpose could be achieved or not; an event may be enjoyable or unpleasant. In the event of an unpleasant experience, a goal-desire conflict will arise which will lead to a specific coping response (e.g., abandoning the goal), while a pleasant experience will lead to emotions such as euphoria, satisfaction, pleasure or love.

The second type of response concerns possible or expected goals, which are divided into two types: (1) goal-desire avoidance (i.e., goals that are anticipated as unpleasant) 
and (2) goal-desire pursuits (i.e., goals that are anticipated as pleasant). Regarding the measurement of emotional self-regulation of the attitude-intention relationship, coping responses can be obtained by asking individuals to recall coping thoughts and actions they have utilized in relation to expected or possible results.

Unlike passive attitudes, subjective norms, and perceived behavioural control, anticipated emotions function dynamically in a self-regulatory sense in response to actual or imagined feedback [51,52]. That is, for a goal that one contemplates, one appraises the consequences of achieving or not achieving that goal, with corresponding positive and negative emotions developing. A comparison is made between one's goal as a standard or reference value, and an estimate is made concerning how one would feel after achieving or failing to achieve the goal. The anticipated emotions finally function to influence decision making by pressing for a decision that either promotes positive emotions or avoids negative emotions.

\subsection{Traveller Motivations and Behaviour}

The research surrounding tourist motivations has been rather extensive, dating back roughly forty years. Crompton $[16,53]$ was one of the first researchers to investigate tourist motivations, focusing on the needs of individual travellers. Bryant and Morrison [54] followed this by focusing on segmenting tourists based on market demands. Ross and Iso-Ahola [55] examined the tourism motivations and satisfactions of tourist travellers. Jamrozy and Uysal [56] observed the motivation of transcultural tourism to understand the behaviour of German travelers, while Cha, McClearly and Uysal [57] focused on Japanese residents' motivations for travelling overseas. Based on the literature surrounding tourists' motivations, it is apparent that not all individuals share the same motivations for visiting a particular destination or type of holiday. Deci and Ryan [58] highlighted such motivational distinctions in their seminal research on the topic. Such work provides insight as to the role environmental factors play in individuals choosing a destination, thus demonstrating that changes in behaviour can be seen through obvious psychosocial mediators [58,59].

Several reasons exist as to why people engage in particular behaviours [60]. Regardless of the experiences, most people tend to rely on their past experiences when trying to satisfy their needs in a new situation. Thus, a positive past experience tends to pave the way for positive future intentions, just as negative experiences can equally explain such intentions not to engage in a particular behaviour in the future. It goes without saying that not all intentions are universal, especially those where coping strategies are implemented by potential travellers.

Several studies underline the importance of emotions in consumer behavior [31], and intentions towards a destination [61]. Despite this, few studies have investigated tourists emotional associations with destinations [62,63].

\subsection{Coping Strategies and Goal-Directed Behavioural Intentions}

Minimal work has been undertaken to determine the influence of coping strategies on the correlation between motivation and goal-directed behavioural intentions [64]. Some studies confirm that negative experiences contribute to tourists' tendency for avoidance. Furthermore, these studies suggest that this behaviour manifests itself as a coping strategy in stressful experiences [65-67]. Another coping strategy that tourists can use is to warn others of the unpleasant experience through negative WOM [68]. This negative WOM turns out to be harmful advertising, given its power to dissuade individuals from selecting a particular destination [69]. Consumers can focus on a number of different coping strategies as a reaction to the experience that can influence the achievement of the goal [70]. If emotions are therefore able to direct the action of the tourist towards the intention to reach the goal (in our case, cultural tourism in Sicily), at the same time, coping factors such as avoidance and negative WOM can influence the relationship.

In the literature, several studies have examined the influence of WOM on destination choice. In general, WOM is considered one of the most important factors influencing 
consumer behavior [71]. This is especially true when individuals are contemplating the purchase of intangible products, such as travel [72]. In essence, WOM provides the potential consumer with greater confidence in purchase decisions.

Based on previous literature, the primary aim of this research is to examine antecedent factors (i.e., emotional and motivational) that contribute to tourists' behavioural intentions of selecting a cultural tourism holiday. As such, the theory of self-regulation is used to formulate and test a model based on the goal-directed behavioural framework to better understand why tourists visit Sicily and engage in cultural tourism. With this knowledge, destination marketing organizations and tourism planners throughout Sicily will be better equipped to meet the needs of potential visitors, helping to ensure this niche form of tourism is sustainably developed and managed. Stated more specifically, this work will examine whether the variables (e.g., attitudes regarding the act, subjective norms, perceived behavioural control, and desire) that predict behavioural intentions to select a cultural tourism holiday can be mediated by emotions (e.g., coping strategies and avoidance) among potential tourists. Based on these aims, the following question guides this research: "Are tourists' attitudes transformed into action based on positive (or negative) emotions developed through their travel experiences?"

The following model (see Figure 1) presents 14 direct effect hypotheses (i.e., $\mathrm{H}_{1}, \mathrm{H}_{2}$, $\mathrm{H}_{3}, \mathrm{H}_{4}$, and $\mathrm{H}_{5}$ ) and 8 indirect effect hypotheses (i.e., $\mathrm{H}_{6}$ and $\mathrm{H}_{7}$ ) related to attitudes about choosing a cultural holiday, subjective norms, perceived behavioural control, desire, emotions (i.e., negative WOM and avoidance) and behavioural intentions towards choosing a cultural holiday. Stated more specifically, those hypotheses are:

Hypothesis $\mathbf{1}\left(\mathbf{H}_{\mathbf{1 a}-\mathbf{1 d}}\right)$. Attitudes about choosing a cultural holiday (a), subjective norms (b), perceived behavioural control (c), and desire (d) will each significantly predict individuals' intentions to choose a cultural heritage holiday.

Hypothesis $2\left(\mathbf{H}_{\mathbf{2 a}-\mathbf{2 d}}\right)$. Attitudes about choosing a cultural holiday (a), subjective norms (b), perceived behavioural control $(c)$, and desire $(d)$ will each significantly predict individuals' negative WOM coping strategies.

Hypothesis 3 ( $\left.\mathbf{H}_{3 \mathbf{a}-3 \mathbf{d}}\right)$. Attitudes about choosing a cultural holiday (a), subjective norms (b), perceived behavioural control (c), and desire (d) will each significantly predict individuals' avoidance coping strategies.

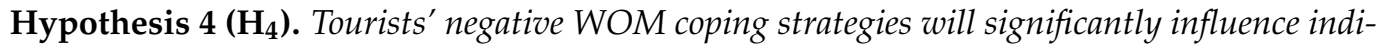
viduals' intentions to choose a cultural heritage holiday.

Hypothesis $\mathbf{5}\left(\mathbf{H}_{5}\right)$. Tourists' avoidance coping strategies will significantly influence individuals' intentions to choose a cultural heritage holiday.

Hypothesis $\mathbf{6}\left(\mathbf{H}_{\mathbf{6 a}-\mathbf{6 d}}\right)$. Tourists' negative WOM coping strategies will mediate the relationship of attitudes about a cultural holiday (a), subjective norms (b), perceived behavioural control (c) and desire (d) with individuals' intentions to choose a cultural heritage holiday.

Hypothesis $\mathbf{7}\left(\mathbf{H}_{7 \mathbf{a}-7 \mathrm{~d}}\right)$. Tourists' avoidance coping strategies will mediate the relationship of attitudes about a cultural holiday (a), subjective norms (b), perceived behavioural control (c), and desire (d) with individuals' intentions to choose a cultural heritage holiday. 
The full hypothesized theoretical framework is depicted in Figure 1.

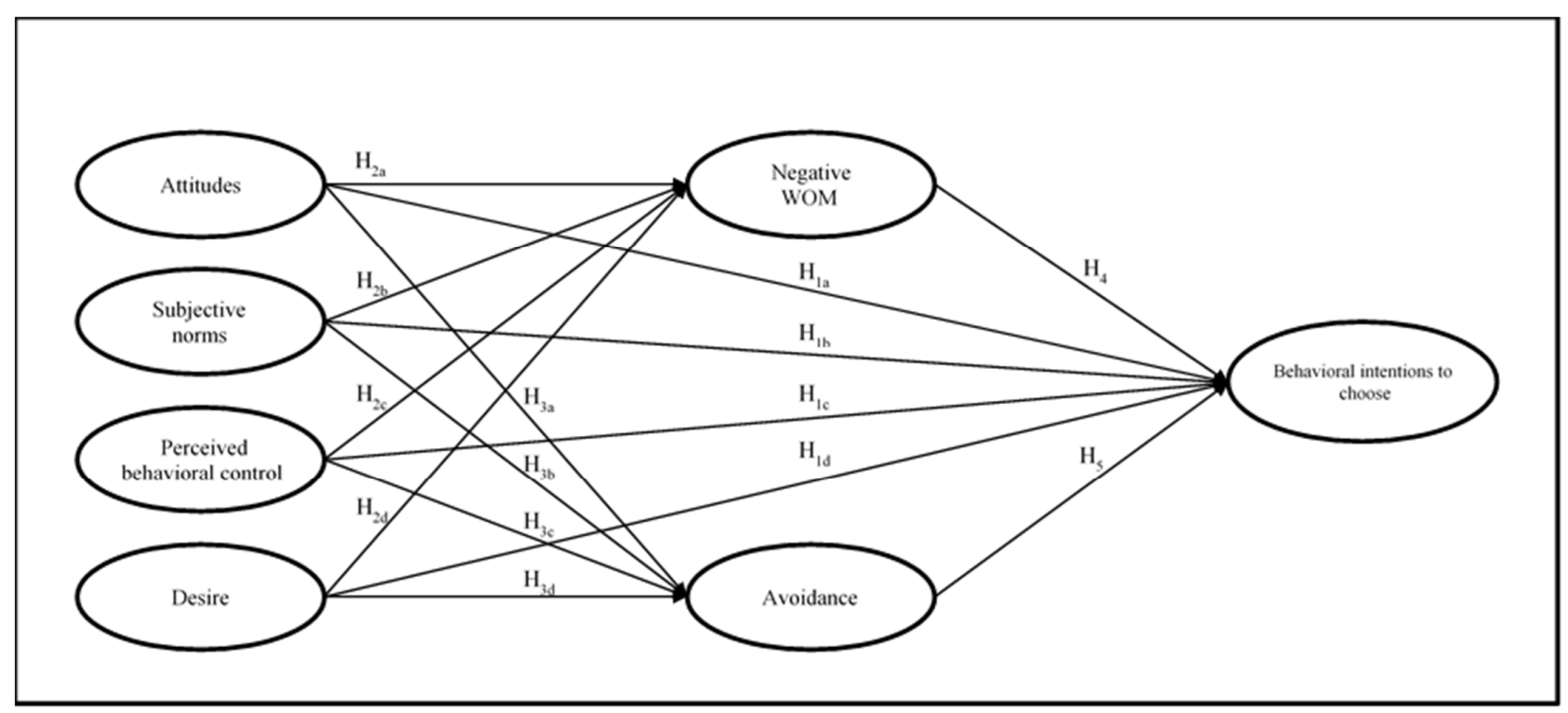

Figure 1. Proposed model $\left(\mathrm{H}_{6 \mathrm{a}-6 \mathrm{~d}}\right.$ indicating the indirect effects of negative WOM and $\mathrm{H}_{7 \mathrm{a}-7 \mathrm{~d}}$ indicating the indirect effects of avoidance not drawn).

\section{Research Methods}

\subsection{Study Context and Data Collection}

As part of the "Old World," Italy is a country that has no shortage of tangible or intangible cultural heritage. According to UNESCO [73], Italy ranks first among all nations with the most World Heritage Sites (WHS): from the Langhe landscapes in the north, to the Arab-Norman domes of Palermo, to the Eternal City (Rome) in the centre. Hundreds of archaeological sites and well over 3000 museums are dedicated throughout Italy to preserving cultural heritage [74]. Southern Italy is a very popular region, with its rich cultural heritage including the remains of Magna Graecia; from the Valley of the Temples, to Agrigento, to the town of Selinunte in Sicily, and moving up the peninsula to Paestum and the Homeric charm of Campi Flegrei in Campania. Sicily, in particular, boasts 7 WHS (of the 51 throughout Italy) listed through UNESCO: (1) Archaeological Area of Agrigento (listed in 1997); (2) Villa Romana del Casale (1997); (3) Isole Eolie (Aeolian Islands, 2000); (4) Late Baroque Towns of the Val di Noto (southeastern Sicily, 2002); (5) Syracuse and the Rocky Necropolis of Pantalica (2005); (6) Mount Etna (2013); and (7) the Arab-Norman Palermo and the Cathedral Churches of Cefalú and Monreale (2015).

Considering potential visitors to Sicily as our study population, participants were recruited by publishing a link to our online questionnaire in two online social media groups (i.e., LinkedIn and Twitter), and they were also approached in workgroups via written correspondence (e.g., email or invitation by letter) to participate. In so doing, a convenience sampling strategy was followed to secure our sample of potential visitors to Sicily. Data were collected online between May 2017 and March 2018. The questionnaire was available in two languages: Italian and English. At the beginning of the survey, participants were asked in which language they would like to complete the questionnaire. By clicking on the corresponding link, they were directed to the questionnaire using the desired language. Of the 743 individuals (i.e., 345 via LinkedIn and 398 via Twitter postings) that accessed the questionnaire, 481 provided responses (i.e., 250 via LinkedIn and 231 via Twitter postings). However, upon closer examination, 12 questionnaires lacked complete responses and were excluded from analysis. This resulted in 469 useable questionnaires (i.e., 240 via LinkedIn for a response rate of $69.6 \%$, and 229 via Twitter for a response rate of $57.5 \%$ ). All participants were volunteers; no compensation was supplied. 
We examined the potential for nonresponse bias by analysing early (the first 10\%) and later (the last 10\%) responses [75]. An independent samples t-test was performed on demographic variables (age, gender, marital status, level of education and occupation) and the results demonstrate that no statistical differences were detected between early and late respondents regarding the respondents' characteristics. Consequently, we conclude that nonresponse was not an issue in our data.

\subsection{Measures}

The online questionnaire included measures for the seven model constructs. Four constructs focused on self-regulation (as related to the self-regulation theory) - attitudes toward act, subjective norms, perceived behavioural control and desire. According to Simons [76] (p. 80), an attitude is a "relatively enduring predisposition to respond favourably or unfavourably towards something." It is defined as the sum of the expected outcomes that is weighted by an evaluation of the desirability of the outcome (Fishbein 1963). Participants were asked to evaluate the concept "The cultural holiday is ... " via 17 7-point semantic differential items [77]; 10 assessed evaluation attitudes (e.g., "useful-useless") and 7 assessed affective attitudes (e.g., "pleasant-unpleasant").

Subjective norms refer to the desire to act as others think you should act, and are therefore internally controlled. This variable was measured by two items (e.g., "My friends support my decision to practice cultural holidays"). Perceived behavioural control indicates an individual's perception that $\mathrm{s} /$ he has the skills and ability to enact a behaviour. This construct is argued to be one of the most important within the theory of reasoned action (TRA) to allow for the prediction of behaviour [78]. This variable was measured through three items (e.g., "If I wanted to, it would be easy for me to visit museums and works of art in Sicily"). The construct of desire differs from attitudes toward an act because it is a conative state that is directed toward approaching or avoiding something [51]. Desire is "the fundamental psychological determinant of intentions" [51] (p. 185). To detect this construct, we utilized three items (e.g., "I would like to return to Sicily to learn more about the culture of its people"). Subjective norms, perceived behavioural control, and desire items were presented on a 4-point Likert scale (from "completely false" to "completely true").

Two coping strategy constructs (i.e., negative WOM and avoidance) were also included in the model. Consistent with the literature [79,80], we define WOM coping strategies as "strategies involving problem-solving efforts that managers take to master, tolerate or minimize WOM considered as a threat to the product, service, markets or company" [81] (p. 126). In consumer psychology research, negative WOM is very important to consumers as regards maintaining a consistent social self-image [82-85]. Negative WOM was measured through three items (e.g., "I would say negative things about the destination to other people"). Avoidance refers to a negative assessment that the tourist makes based on an experience [86,87]. The reasons for the negative evaluation can be multiple [88]. Such avoidance behaviour means that the "individual emotional relief and can be defined as consumers' attempt to regulate their emotions through mental or physical detachment from a harmful or distressing situation" [64] (p. 212). Avoidance was measured through two items (e.g., "I would go on as if nothing has happened"). Negative WOM and avoidance items were presented on a 4-point Likert scale (from "completely false" to "completely true").

Behavioural intentions to participate in cultural tourism served as the ultimate outcome construct within the model. As such, it was measured using three items (e.g., "It is likely I will return to Sicily to visit the scenery and its historical beauties") using a 4-point Likert scale (from "very unlikely" to "very likely"). In addition to these seven model constructs, participants were asked to respond to four demographic questions (e.g., gender, country of origin, level of education, and household income) and two questions relating to recent travel behaviour (e.g., trips made in the last two years and trips made in the last two years to different places). 


\subsection{Data Analysis}

Prior to analysis, data were screened to ensure no outliers were present. A confirmatory factor analysis (CFA) was then used to test the fit of the measurement model [89] and examine the psychometrics of each construct. AMOS provides several goodness-of-fit indexes, including the chi-square $\left(\chi^{2}\right)$, the comparative fit index (CFI), the Root Mean Square Error of Approximation (RMSEA), and the Standardized Root Mean Square Residual (SRMR). Akaike Information Criterion (AIC) and Bayesian Information Criterion (BIC) were also presented (lower values indicate better fit). AMOS was utilised given that it allows for CFA and structural equation modelling concurrently. The $\chi^{2}$ test examines the null hypothesis that the covariance matrix and mean vector in the population are equal to the model-implied covariance matrix and mean vector [90]. A significant $\chi^{2}$ value leads to the rejection of the null hypothesis that the model fits the population. Because the $\chi^{2}$ is highly sensitive to sample size (i.e., the larger the sample size, the more likely to reject the model), the ratio chi-square $\left(\chi^{2}\right)$ /degrees of freedom ( $\left.\mathrm{df}\right)$ is frequently analysed. Kline [91] recommends that a $\chi^{2} / \mathrm{df}$ greater than 3.0 represents inadequate fit. According to $\mathrm{Hu}$ and Bentler [92], a CFI in excess of 0.95 can indicate a good model fit. The RMSEA is a measure of approximate model fit. According to Browne and Cudeck [93], an RMSEA less than 0.09 is also an indicator of a reasonable error of approximation in smaller samples. Finally, the SRMR coefficient is a standardized measure for the evaluation of the model residuals, with critical values as high as 0.08 considered acceptable [92].

Once the measurement model was established through CFA, linear structural equation models were calibrated to test the hypothesised relationships in the mediation model in Figure 1, also using AMOS 25.0 [94], and in keeping with Shrout and Bolger's [95] logic with regard to expected proximal and distal effects. Other well-known analytical tools, such as correlations, were also used, implemented using SPSS 25.0. In order to optimise the sample size, missing values for the relevant items were estimated using the Expectation Maximisation method. None of the items had more than $5 \%$ missing values, indicating that this option was appropriate [96].

\section{Results}

\subsection{Sample Profile}

Of the 469 completed questionnaires, $58.6 \%$ were finished by females. Respondents mainly included young adult tourists in the age groups of 18-29 (40.7\%) and 30-39 (24.5\%). Most respondents were from Italy $(67.6 \%)$, followed by other European countries (29.7\%), the USA $(2.3 \%)$, and others $(0.4 \%)$. A preponderance of individuals $(67.0 \%)$ had obtained a bachelor's degree. Finally, a majority of the sample participants had an income of less than EUR 12,000 (52.0\%), had completed 1-5 trips in the last two years $(65.7 \%)$ and had done so in at least two different places (56.3\%) (See Table 1).

Table 1. Sample characteristics.

\begin{tabular}{lcc}
\hline & Frequency (s) & Percentage \% \\
\hline Gender & & \\
Male & 194 & 41.4 \\
Female & 275 & 58.6 \\
Age & & \\
$18-29$ & 191 & 40.7 \\
$30-39$ & 115 & 24.5 \\
$40-49$ & 97 & 20.7 \\
$50-59$ & 47 & 10.0 \\
$\geq 60$ & 19 & 4.1 \\
\hline
\end{tabular}


Table 1. Cont.

\begin{tabular}{lcc}
\hline & Frequency (s) & Percentage $\%$ \\
\hline Country of Origin & 317 & 67.6 \\
Italy & 139 & 29.7 \\
Rest of Europe & 11 & 2.3 \\
USA & 2 & 0.4 \\
Other & & \\
Level of Education & 13 & 2.8 \\
Middle School & 73 & 15.6 \\
High School & 314 & 67.0 \\
Bachelor's Degree & 14 & 2.9 \\
Master's Degree & 55 & 11.7 \\
Doctoral Degree & & \\
Income & 244 & 52.0 \\
Less than EUR 12,000 & 134 & 28.6 \\
EUR 12,001-25,000 & 78 & 16.6 \\
EUR 25,001-45,000 & 5 & 1.1 \\
EUR 45,001-60,000 & 8 & 1.7 \\
Over EUR 60,000 & & \\
Trips made in the last two years & 308 & 65.7 \\
From 1 to 5 & 101 & 21.6 \\
From 6 to 10 & 24 & 5.1 \\
From 11 to 15 & 11 & 2.3 \\
From 16 to 20 & 25 & 5.3 \\
Over 20 & & \\
Trips made in the last two years in different places & 264 & 5.0 \\
From 1 to 5 & 90.3 \\
From 6 to 10 & 68 \\
From 11 to 15 & 33 & 14.5 \\
From 16 to 20 & 14 & \\
Over 20 & & \\
\hline & & \\
& & \\
\hline
\end{tabular}

\subsection{Measurement Model Evaluation}

All the variables studied were measured from the same source, and therefore commonmethod bias may have occurred. A CFA according to Harman's single-factor test was used to diagnose the extent to which common-method variance was a problem [97]. A comparison between the hypothesised model and a model with one factor (with all items loading on a unique factor) revealed that the former provided a better fit for the data in all the CFA fit measures. CFA was performed using robust maximum likelihood estimation to examine the structure of the constructs. Two different models were tested and compared. The first model included eight factors, considering all scales with a single-factor structure, but for attitude toward acting (i.e., evaluative attitudes and affective attitudes), a factorial structure of second order was used. The results of this model provided a reasonably good fit to the data: $\chi^{2}[11, n=469]=35.236, p=0.002, \chi^{2} / \mathrm{df}=3.20$, RMSEA $=0.07$ (C.I. $=0.075-0.086), \mathrm{CFI}=0.98, \mathrm{GFI}=0.98$, SRMR $=0.08$. Moreover, the AIC and BIC values were 141.235 and 176.91 , respectively. The second CFA model included the same factors but considered all scales with a single-factor structure, and also for attitude toward acting, in which all indicators loaded onto one factor. The results of this model provided a better fit to the data, so the general model of CFA suggests a seven-factor solution $\left(\chi^{2}[3, n=469]=8.415, p=0.038, \chi^{2} / \mathrm{df}=2.80, \mathrm{RMSEA}=0.06(\mathrm{CI}=0.048-0.065), \mathrm{CFI}=0.99\right.$, GFI $=0.99$, SRMR $=0.03$, AIC $=58.415 ;$ BIC $=162.180$ ). This second model fit the data significantly better than the first, not only for the values of fit indices but also for the $\chi^{2}$ difference test $\left(\Delta \chi^{2}(8)=26.821, p<0.001\right)$. According to these results, we found no evidence of common-method bias in the data.

The construct validity of the model was assessed by measuring convergent and discriminant validities. The reliability analysis confirmed that the model demonstrated a high level of internal consistency with Cronbach's alpha values greater than 0.70 . The composite 
reliabilities (CR) exceeded the threshold value of 0.70 [98], indicating the construct reliability of the measurement scales, with $\mathrm{CR}$ values ranging from 0.79 to 0.96 , providing evidence of convergent validity. The AVE values of all constructs ranged from 0.62 to 0.82 , exceeding the recommended threshold of 0.50 [98]. In addition, convergent validity (Table 2) was assumed based on the statistically significant $(p<0.001$ and $p<0.005)$ item loadings [99].

To measure the statistical power of the sample, we conducted a post-hoc calucation of statistical power using multiple regression analysis. The power of the hypothesis test is between 0 and 1; if the power is close to 1 , the hypothesis test is very good. The results showed an observed statistical power of 1.0, with a probability level at 0.05 [100].

Table 2. Results of the measurement model: reliability and convergent validity.

\begin{tabular}{|c|c|c|c|c|}
\hline Constructs and Indicators & Mean (SD) & Skewness/Kurtosis & $\beta$ & t-Values \\
\hline \multicolumn{5}{|l|}{ Attitudes concerning choosing cultural tourism $(\alpha=0.78 ; \mathrm{AVE}=0.72 ; \mathrm{CR}=0.96)$} \\
\hline \multicolumn{5}{|l|}{ Evaluative attitudes } \\
\hline Appreciable/Depreciable & $3.62(0.52)$ & $1.87 / 4.04$ & 0.848 & $\mathrm{~N} / \mathrm{A}^{\mathrm{a}}$ \\
\hline Useful/Useless & $4.63(0.48)$ & $-0.52 /-1.74$ & 0.790 & $15.22 * * *$ \\
\hline Effective/Ineffective & $4.93(0.68)$ & $1.12 / 2.57$ & 0.826 & $19.82 * *$ \\
\hline Unreliable/Reliable & $6.18(0.73)$ & $-0.29 /-1.10$ & 0.758 & $14.90^{* * *}$ \\
\hline Pleasant/Unpleasant & $4.42(0.49)$ & $0.34 /-1.88$ & 0.985 & $28.83^{* * *}$ \\
\hline Fine/Despicable & $4.47(0.87)$ & $0.11 /-1.99$ & 0.841 & $21.58^{* * *}$ \\
\hline Nice/Ugly & $4.30(0.50)$ & $0.89 /-1.12$ & 0.986 & $29.26 * * *$ \\
\hline Bad/Good & $6.08(0.51)$ & $-1.95 / 3.64$ & 0.798 & $16.61^{* * *}$ \\
\hline Meaningful/Meaningless & $4.92(0.50)$ & $1.07 / 6.37$ & 0.817 & $17.67^{* * *}$ \\
\hline \multicolumn{5}{|l|}{ Affective attitudes } \\
\hline Powerless/Powerful & $2.38(0.38)$ & $0.25 /-1.42$ & 0.833 & $\mathrm{~N} / \mathrm{A}^{\mathrm{a}}$ \\
\hline Stupid/Smart & $6.36(0.87)$ & $-1.06 /-0.06$ & 0.757 & $13.03^{* *}$ \\
\hline Weak/Strong & $4.64(0.52)$ & $-0.12 /-1 / 04$ & 0.866 & $22.87^{* * *}$ \\
\hline Sad/Cheerful & $4.43(0.50)$ & $0.28 /-1.92$ & 0.978 & $28.90^{* * *}$ \\
\hline Passive/Active & $4.40(0.51)$ & $0.68 /-0.91$ & 0.838 & $18.96^{* * *}$ \\
\hline Static/Dynamic & $4.75(0.50)$ & $0.61 / 1.20$ & 0.821 & $17.66^{* * *}$ \\
\hline Delicate/Solid & $4.74(0.62)$ & $0.78 / 0.58$ & 0.842 & $19.67 * * *$ \\
\hline \multicolumn{5}{|l|}{ Subjective norms $(\alpha=0.74 ; \mathrm{AVE}=0.66 ; \mathrm{CR}=0.79)$} \\
\hline My parents support my decision to undertake cultural tourism & $3.50(0.72)$ & $-1.54 / 2.28$ & 0.717 & $\mathrm{~N} / \mathrm{A}^{\mathrm{a}}$ \\
\hline My friends support my decision to engage in cultural tourism & $2.97(1.02)$ & $-0.64 /-0.74$ & 0.899 & $23.85^{* * *}$ \\
\hline \multicolumn{5}{|l|}{ Negative WOM $(\alpha=0.84 ; \mathrm{AVE}=0.62 ; \mathrm{CR}=0.83)$} \\
\hline I would complain about the dest to others & $3.79(0.85)$ & $0.42 /-1.49$ & 0.717 & $\mathrm{~N} / \mathrm{A}^{\mathrm{a}}$ \\
\hline I would say neg things about dest to others & $3.73(0.89)$ & $0.57 /-1.50$ & 0.888 & $16.23 * * *$ \\
\hline I would recommend others to not visit & $3.62(0.78)$ & $0.77 /-0.95$ & 0.747 & $15.23 * * *$ \\
\hline \multicolumn{5}{|l|}{ Perceived behavioural control $(\alpha=0.72 ; \mathrm{AVE}=0.69 ; \mathrm{CR}=0.87)$} \\
\hline $\begin{array}{l}\text { If I wanted to, it would be easy for me to choose a cultural tourism } \\
\text { holiday again }\end{array}$ & $3.49(0.86)$ & $-1.76 / 2.24$ & 0.686 & $\mathrm{~N} / \mathrm{A}^{\mathrm{a}}$ \\
\hline $\begin{array}{l}\text { If I wanted to, it would be easy for me to visit museums and works of art } \\
\text { in Sicily }\end{array}$ & $3.67(0.62)$ & $-1.72 / 1.66$ & 0.799 & $20.21 * * *$ \\
\hline $\begin{array}{l}\text { If I wanted to, it would be easy for me to choose to choose to visit landscapes } \\
\text { of Sicily again }\end{array}$ & $3.47(0.67)$ & $-0.90 /-0.38$ & 0.975 & $24.75^{* * *}$ \\
\hline \multicolumn{5}{|l|}{ Desire $(\alpha=0.83 ; \mathrm{AVE}=0.82 ; \mathrm{CR}=0.93)$} \\
\hline I would like to return to Sicily to learn more about the culture of its people & $3.62(0.70)$ & $-2.22 / 5.05$ & 0.969 & $\mathrm{~N} / \mathrm{A}^{\mathrm{a}}$ \\
\hline I would love to go back to Sicily & $3.68(0.63)$ & $-2.37 / 6.22$ & 0.930 & $24.15 * * *$ \\
\hline $\begin{array}{l}\text { I would like to return to Sicily to review the landscapes and its } \\
\text { historical beauties }\end{array}$ & $3.68(0.57)$ & $-2.03 / 5.06$ & 0.818 & $17.36^{* * *}$ \\
\hline \multicolumn{5}{|c|}{ Behavioural intentions to engage in cultural tourism $(\alpha=0.71 ; \mathrm{AVE}=0.69 ; \mathrm{CR}=0.87)$} \\
\hline I would like to get back to cultural tourism & $3.39(0.74)$ & $-1.36 / 2.07$ & 0.898 & $\mathrm{~N} / \mathrm{A}^{\mathrm{a}}$ \\
\hline It is highly like I will return to Sicily & $3.63(0.61)$ & $-1.78 / 3.45$ & 0.896 & $26.19 * * *$ \\
\hline It is likely I will return to Sicily to visit the Scenery and its historical beauties & $3.48(0.71)$ & $-1.44 / 2.11$ & 0.671 & $9.78 * * *$ \\
\hline
\end{tabular}

Notes: $\alpha=$ Cronbach's alpha; AVE: average variance extracted; CR: composite reliability. ${ }^{* * *} p<0.001,{ }^{* *} p<0.005 .{ }^{\text {a }}$ in AMOS, one loading has to be fixed to 1 ; hence, the $t$-value cannot be calculated for this item.

In SEM, one of the main concerns about the data is whether the sample has a multivariate normal distribution, because that determines which estimation method will be used and to what extent the estimates obtained from the most common methods are trustworthy [101]. Each observed variable has minimum, maximum, skewness, and kurtosis values. Values greater than 2.0 for skewness and greater than 7.0 for kurtosis indicate the non-normality of the data. In Table 3, the results show that no item presented a skewness 
or kurtosis level higher than these thresholds, indicating the normality of the data. In addition, the multivariate normality of the distribution was evaluated through the Mardia coefficient. According to Bollen [102], if the Mardia coefficient is less than $\mathrm{P}(\mathrm{P}+2)$, where $\mathrm{P}$ is the number of observed variables, multivariate normality can be deduced. In our study, the Mardia coefficient was 27.16, demonstrating that the observed distribution falls within the normality values for all the variables included in the model.

In Table 3, significant correlations were found between behavioural intentions and all other factors within the model. The same can be said for the relationship between subjective norms and perceived behavioural control and avoidance. Furthermore, there was a strong correlation between desire and behavioural intentions $\left(r=0.67^{* *}\right)$. Discriminant validity was assessed by calculating the square root of the AVE for each specified construct. Table 3 reveals that the square root of AVE (presented in the diagonal) for each construct was greater than its correlation with all other constructs, providing support of discriminant validity amongst all constructs in the measurement model [98].

Table 3. Discriminant validity results.

\begin{tabular}{|c|c|c|c|c|c|c|c|}
\hline Constructs $^{a}$ & 1 & 2 & 3 & 4 & 5 & 6 & 7 \\
\hline Behavioural intentions & $0.83^{b}$ & & & & & & \\
\hline Attitudes regarding cultural tourism & $-0.44^{* *}$ & 0.85 & & & & & \\
\hline Subjective norms & $-0.37^{* *}$ & $-0.39 * *$ & 0.81 & & & & \\
\hline Negative WOM & $-0.20^{* *}$ & $-0.17 * *$ & $0.22 * *$ & 0.79 & & & \\
\hline Perceived behavioural control & $-0.39 * *$ & $-0.14^{* *}$ & $0.24^{* *}$ & $0.26 * *$ & 0.83 & & \\
\hline Desire & $0.67 * *$ & $-0.45^{* *}$ & $0.37 * *$ & 0.08 & $0.48^{* *}$ & 0.91 & \\
\hline Avoidance & $-0.14^{* *}$ & $-0.11^{* *}$ & $0.32 * *$ & 0.06 & $0.48 * *$ & $0.25^{* *}$ & 0.87 \\
\hline
\end{tabular}

${ }^{a} 469$ individuals responded to all items within each construct. ${ }^{b}$ The bolded diagonal elements are the square root of the average variance extracted; interconstruct correlations are shown below the diagonal. ${ }^{* *}$ correlations are significant at the $p<0.001$ level.

\subsection{Structural Model Evaluation}

Multiple mediation analysis was conducted using AMOS software, version 25.0 [94]. The effects of multiple mediator variables can be tested individually and simultaneously. The advantage of simultaneous testing is the ability to learn whether the effects of one mediator and another are independent [103]. Behavioural intentions were therefore entered as the dependent variable, while attitude toward acting, subjective norms, perceived behavioural control and desire were independent variables; negative WOM and avoidance were entered as mediators. All variables were entered as latent constructs, with the exception of behavioural intentions, which was entered as an observed construct. The bootstrapping method (i.e., 2000 samples) was used with bias-corrected (BC) confidence intervals in order to obtain more powerful confidence interval limits for indirect effects (95\% CI) [104].

\subsection{Direct Effects}

As shown in Figure 2, the results revealed a direct effect of all predictors on behavioural intentions, thus supporting Hypothesis 1. Specifically, behavioural intention was significantly related to attitudes concerning choosing a cultural holiday $\left(\mathrm{H}_{1 \mathrm{a}}, \beta=0.29\right.$; $p<0.001)$, subjective norms $\left(\mathrm{H}_{1 \mathrm{~b}}, \beta=0.12 ; p<0.01\right)$, perceived behavioural control $\left(\mathrm{H}_{1 \mathrm{c}}\right.$, $\beta=0.53 ; p<0.001)$ and desire $\left(\mathrm{H}_{1 \mathrm{~d}}, \beta=0.14 ; p<0.01\right)$. Hypothesis 2 was also confirmed; attitudes concerning choosing a cultural holiday $\left(\mathrm{H}_{2 \mathrm{a}}, \beta=-0.14 ; p<0.001\right)$, subjective norms $\left(\mathrm{H}_{2 b}, \beta=0.16 ; p<0.01\right)$, perceived behavioural control $\left(\mathrm{H}_{2 c}, \beta=0.10 ; p<0.05\right)$ and desire $\left(\mathrm{H}_{2 \mathrm{~d}}, \beta=-0.18 ; p<0.01\right)$ predicted individuals' negative WOM coping strategies. Hypothesis 3 was only partially confirmed. Subjective norms $\left(\mathrm{H}_{3 b}, \beta=0.22 ; p<0.001\right)$ and perceived behavioural control $\left(\mathrm{H}_{3 \mathrm{c}}, \beta=0.42 ; p<0.001\right)$ significantly explained avoidance coping strategies; however, attitudes concerning choosing a cultural holiday $\left(\mathrm{H}_{3 a}\right.$, $\beta=-0.02 ; p=0.729)$ and desire $\left(\mathrm{H}_{3 \mathrm{~d}}, \beta=-0.03 ; p=0.673\right)$ did not significantly explain 
avoidance coping strategies. Moreover, negative WOM coping strategies $\left(\mathrm{H}_{4}, \beta=0.09\right.$; $p<0.05)$ and avoidance coping strategies $\left(\mathrm{H}_{5}, \beta=-0.10 ; p<0.05\right)$ significantly explained behavioural intentions. The proposed structural model explained a significant amount of variance in each construct. Specifically, the model explained $47 \%$ of the variance in negative WOM coping strategies, $35 \%$ of the variance in avoidance coping strategies and $53 \%$ of the variance in behavioural intention.

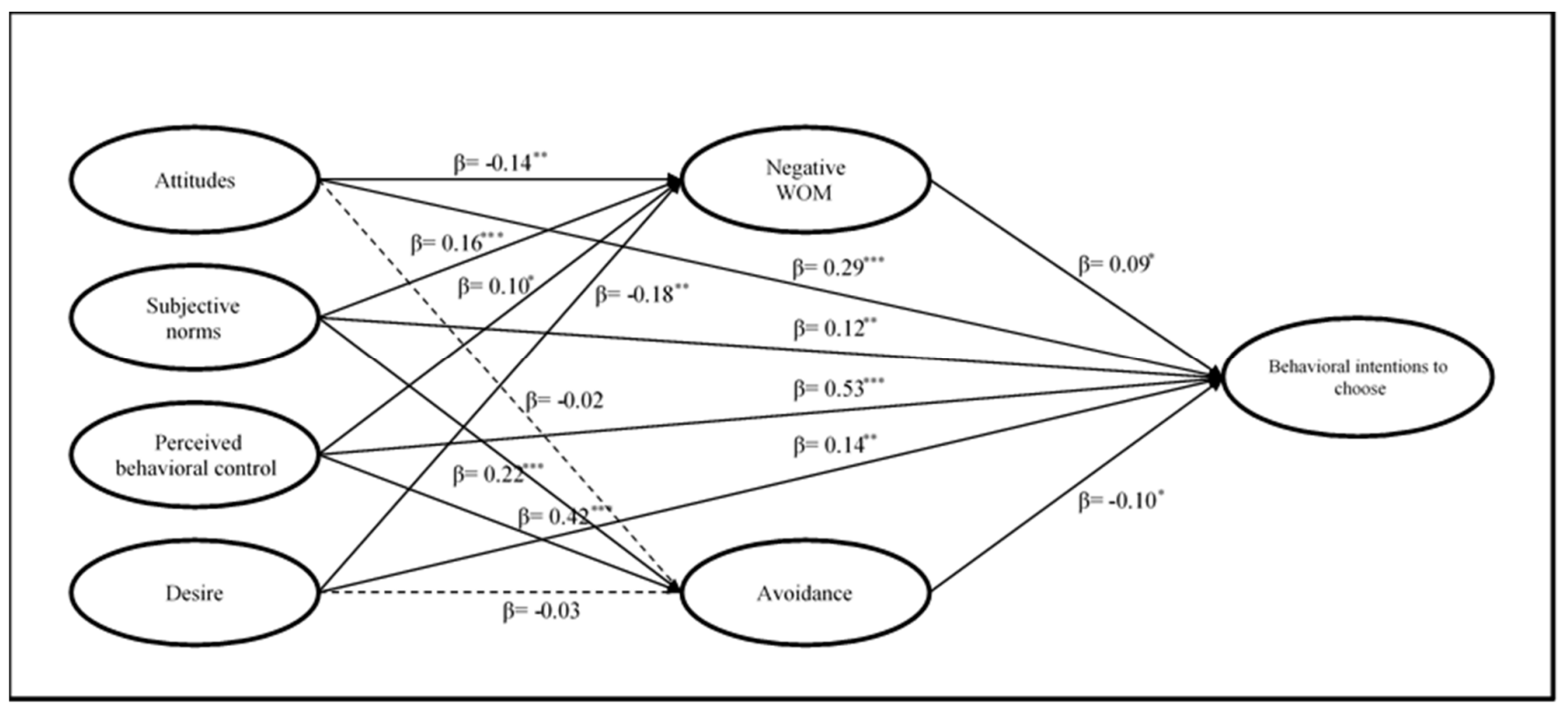

Figure 2. Final SEM $\left(\mathrm{H}_{6 \mathrm{a}-6 \mathrm{~d}}\right.$ indicating indirect effects of negative WOM and $\mathrm{H}_{7 \mathrm{a}-7 \mathrm{~d}}$ indicating indirect effects of avoidance not drawn) ${ }^{* *} p<0.001,{ }^{* *} p<0.01,{ }^{*} p<0.05$.

\subsection{Indirect Effects}

The statistical significance of indirect effects within the tested model was examined on 2000 bootstrap samples. Estimations were tested within the $95 \%$ confidence interval (CI) and were bias-corrected, and accelerated results are included. As presented in Table 4, Hypothesis 6 was supported, since the bootstrap CIs do not cross zero. The results indicate that negative WOM coping strategies mediated the effects of attitudes concerning choosing a cultural holiday $\left(\mathrm{H}_{6 \mathrm{a}}: \beta=0.06, p<0.01,95 \% \mathrm{CI}(0.126,0.324)\right)$, subjective norms $\left(\mathrm{H}_{6 \mathrm{~b}}\right.$ : $\beta=0.03, p<0.001,95 \% \mathrm{CI}(0.032,0.568))$, perceived behavioural control $\left(\mathrm{H}_{6 \mathrm{c}}: \beta=0.06\right.$, $p<0.001,95 \% \mathrm{CI}(0.055,0.486))$, desire $\left(\mathrm{H}_{6 \mathrm{~d}}: \beta=0.07, p<0.001,95 \% \mathrm{CI}(0.041,0.004)\right)$ and behavioural intentions.

Hypothesis 7 was only partially confirmed. The results reveal that avoidance coping strategies mediated the effects of attitudes concerning choosing a cultural holiday $\left(\mathrm{H}_{7 \mathrm{a}}\right.$ : $\beta=0.04, p<0.05,95 \% \mathrm{CI}(0.085,0.017))$ and subjective norms $\left(\mathrm{H}_{7 \mathrm{~b}}: \beta=0.05, p<0.01\right.$, $95 \%, \mathrm{CI}(0.054,0.167))$ on behavioural intentions. Conversely, avoidance coping strategies did not mediate the relationship between perceived behavioural control $\left(\mathrm{H}_{7 \mathrm{c}}: \beta=-0.02\right.$; $p=0.729)$ and behavioural intentions, nor the relationship between desire $\left(\mathrm{H}_{7 \mathrm{~d}}: \beta=-0.03\right.$, $p=0.673$ ) and behavioural intentions, given that the indirect paths were not significant (Table 4). Thus, $\mathrm{H}_{7 \mathrm{a}}$ and $\mathrm{H}_{7 \mathrm{~b}}$ were supported, while $\mathrm{H}_{7 \mathrm{c}}$ and $\mathrm{H}_{7 \mathrm{~d}}$ were rejected. 
Table 4. Standardized indirect effects.

\begin{tabular}{|c|c|c|c|c|}
\hline \multirow{2}{*}{ Predictor } & \multirow{2}{*}{$\beta$} & \multirow{2}{*}{ SE } & \multicolumn{2}{|c|}{ Boot $95 \%$ CI } \\
\hline & & & LL & UL \\
\hline $\mathrm{H}_{6 \mathrm{a}}:$ Attitudes $\rightarrow$ Negative WOM $\rightarrow$ Behavioural intention & $0.06^{* * *}$ & 0.04 & 0.126 & 0.324 \\
\hline $\mathrm{H}_{6 \mathrm{~b}}:$ Subjective norms $\rightarrow$ Negative WOM $\rightarrow$ Behavioural intention & $0.03^{* * *}$ & 0.02 & 0.032 & 0.568 \\
\hline $\mathrm{H}_{6 \mathrm{c}}$ : Perceived behavioural control $\rightarrow$ Negative WOM $\rightarrow$ Behavioural intention & $0.06^{* * *}$ & 0.03 & 0.055 & 0.486 \\
\hline $\mathrm{H}_{6 \mathrm{~d}}:$ Desire $\rightarrow$ Negative WOM $\rightarrow$ Behavioural intention & $0.07 * *$ & 0.06 & 0.041 & 0.004 \\
\hline $\mathrm{H}_{7 \mathrm{a}}:$ Attitudes $\rightarrow$ Avoidance $\rightarrow$ Behavioural intention & $0.04 *$ & 0.05 & 0.085 & 0.017 \\
\hline $\mathrm{H}_{7 \mathrm{~b}}:$ Subjective norms $\rightarrow$ Avoidance $\rightarrow$ Behavioural intention & $0.05^{* *}$ & 0.03 & 0.054 & 0.167 \\
\hline $\mathrm{H}_{7 \mathrm{c}}$ : Perceived behavioural control $\rightarrow$ Avoidance $\rightarrow$ Behavioural intention & $0.07^{\mathrm{ns}}$ & -0.02 & -0.023 & 0.101 \\
\hline $\mathrm{H}_{7 \mathrm{~d}}$ : Desire $\rightarrow$ Avoidance $\rightarrow$ Behavioural intention & $0.07^{\mathrm{ns}}$ & -0.03 & -0.350 & 0.170 \\
\hline
\end{tabular}

Note: $\mathrm{ns}=$ not significant. ${ }^{* * *} p<0.001,{ }^{* *} p<0.01,{ }^{*} p<0.05$.

\section{Discussion}

This study proposed and empirically tested an integrative model that investigated the motivational and emotional determinants of visitors' behavioural intentions of engaging in cultural tourism. The results reveal that the effects of attitudes, subjective norms, perceived behavioural control and desire significantly affect tourists' intentions to choose cultural tourism. The results also reveal that these four goal-directed motivation factors were significant predictors of negative WOM, while only subjective norms and perceived behavioural control predicted avoidance. The findings also reveal that the two dimensions of anticipated emotion, namely negative WOM and avoidance, were determinants of intentions to choose cultural tourism holidays. The findings of this study also demonstrate that negative WOM mediated the indirect effects of attitudes, subjective norms, perceived behavioural control and desire on intentions to choose cultural tourism. Finally, the results indicate that the indirect effects of subjective norms and perceived behavioural control on intentions to choose cultural tourism were mediated by avoidance, whereas the indirect effects of attitudes and desire on intentions to choose cultural tourism (via avoidance) were found to be insignificant. These findings offer important theoretical and managerial implications.

\subsection{Theoretical Implications}

Our study makes three main theoretical contributions to the literature surrounding cultural tourism. First, rooted in the theory of self-regulation or model goal-directed behavior (MGB), this study extends this model to better understand tourists' cognitive and affective decision-making when engaging in cultural tourism. The inclusion of essential and key constructs when developing and extending a theoretical framework in the domain of the consumer decision-making process was shown to be reliable and valid. The empirical results of the extended model highlight the importance of desire as a determinant of anticipated emotions and behavioral intention. Consequently, the extension of the theoretical model also includes anticipated emotions of negative WOM and avoidance as key mediating mechanisms in the relationship between goal-directed motivation and behavioral intentions to choose cultural holidays. The extension, modification and inclusion of new variables with MGB and TPB models are in line with previous research $[47,105,106]$. This work also responds to the calls of other scholars $[45,107,108]$, who highlighted the need for a revision of the current socio-psychological theories to include new variables that are essential within a particular setting or that modify existing paths among latent constructs.

Second, the two dimensions of anticipated emotions, namely negative WOM and avoidance, were revealed to be two important proximal determinants of volitional process (i.e., intentions). Here, we proposed and provided empirical evidence that anticipated emotions provided the motivational impetus for intentions to act, and suggested that attitudes, subjective norms, perceived behavioral controls and desire are antecedents in 
decision-making via anticipated emotions, en route to influencing intentions. Specifically, these two dimensions of anticipated emotion were found to be key mediating mechanisms in the effects of MGB constructs (i.e., attitudes, subjective norms, perceived behavioral control and desire) on tourists' behavioral intentions to engage in cultural tourism. Furthermore, the inclusion of these two anticipated emotions as mediating variables helps to elicit the representation of goal-directed behaviors in the MGB and increase the predictive power of the theoretical model. Additionally, this finding demonstrated the importance of the inclusion of anticipated emotion in the decision-making process, and corroborates the assertion proposed by Bagozzi et al. [109]. The authors argue that individuals consider when to act or not in a goal-directed situation by considering the emotional consequences of both achieving and not achieving the sought-after goal, which Gleicher et al. [110] termed "prefactual appraisals". This perspective expands the theoretical underpinning of the effect of goal-directed motivation on volitional process via anticipated emotions, thereby adding knowledge to the tourist behaviour literature.

Third, our findings reveal that goal-desire is structurally different from behavioural intentions to engage in cultural tourism, providing support for Perugini and Bagozzi's [111] reasoning of a theoretical and empirical difference between desires and intentions. When desires were considered simultaneously with other MGB constructs, they were able to explain $20 \%$ of the variance in negative WOM, $27 \%$ of the variance in avoidance, and $50 \%$ of the variance in behavioural intentions to engage in cultural tourism, demonstrating a robust power to explain visitors' behavioural intentions to engage in cultural tourism. These results contradict previous studies [48,106,112,113], which applied MGB throughout a broad range of behavioural domains (e.g., brand-related behaviour, dieting, alcohol consumption, exercise, learning software, information search, pro-environmental behaviour in festivals, visa exemption, etc.), and which failed to support a theoretical claim of the relationship between desire and intentions, but instead revealed that these two constructs were highly correlated. In this sense, our results show that through construct validity and reliability analyses, the constructs of desire and behavioural intention are theoretically distinct, with high levels of explanatory power. All in all, our proposed framework, wherein desire is considered an independent variable (contrary to previous studies that consider it as a mediator), provides an in-depth description of the psychosocial and emotional determinants of tourists' intentions to engage in cultural tourism.

\subsection{Practical Implications}

From a practical perspective, this study provides several contributions and offers a reflection on the relationship that the tourist forms with the place visited, in terms of the desire to be satisfied through cultural tourism. First, the results suggest that coping strategies play a fundamental role in this relationship by defining tourists' intentions to enjoy cultural tourism in specific places. This means that the experiences gained via tourists' visits and the image created about what the place has to offer are very important as regards fulfilling desires. All predictive variables used in the model were found to be effective in determining the effect on behavioural intention. These results can be of help and offer suggestions to professionals and marketers, who can thus understand, both separately and jointly, the effect that each of these variables has on tourists' behaviours, and on the possibility of identifying with a cultural holiday, and the choice of the place that can respond to such needs. This provides valuable and important suggestions regarding the factors that can inhibit or aid this choice, in order to favour the appropriate factors.

Furthermore, the results relating to the perception of cultural tourism and tourists needs to be able to take advantage of the beauty and amenities of the place in terms of accessibility and ease can certainly offer useful suggestions for DMOs (destination marketing organizations) and those responsible for destination management. The results show how perceived behavioural control has a predictive effect on behavioural intention and is mediated by negative WOMs and avoidance. For the tourist, it is essential to be able to perceive that they have the scope and the ability to enact a behaviour. The territory 
and marketing policies must be able to favour this opportunity. This is especially relevant when it comes to cultural tourism, the accessibility of the place, the possibility of visiting an attraction or destination in order to have an experience that is as pleasant as possible in terms of usability, all of which are important to ensuring that the tourist does not develop avoidance behaviours towards the place and provide negative WOM. Therefore, managers should provide greater clarity and transparency in the information given on-site, greater emotional involvement, and develop a desire towards the place. The aspects that emerged during this study acquire greater significance if we assess them under the current situation due to the COVID-19 pandemic. Tourism in every part of the world has been affected, but there are territories that more than any others derive most of their economic needs from tourism. This is the case of Italy, especially Sicily, a land of great culture and history. A return of tourism to some sense of normalcy will not be easy, and the findings of this study could provide useful indications for cultural tourism destinations to cope and revive the tourism industry as we wrestle with the COVID-19 pandemic. DMOs and practitioners must start again by offering tourists certainty and safe conditions that place such visitors at the centre of the touristic visit, which provide opportunities to safely take advantage of all the beauties of the place and allow for the rediscovery of emotional pleasure derived from the desire to visit. The tourist must feel enriched by the acquisition of the traditions, culture and identity of the place, in order to be able to realise the full benefits of the visit.

\subsection{Limitations and Future Research}

This study is not without its limitations. Though convenience sampling is extremely useful in securing a robust sample size for executing CFA-SEM and mediation analyses, such an approach is limiting, in that it reduces the ability to generalise research findings and increases the potential for sampling bias and sampling error [114]. Nevertheless, convenience sampling may be the only option available in certain situations (for more information see [115]), especially in ours.

Although socio-demographic differences were reported in this research, these variables have only been described, and were not used within model analysis. One of the limitations of our research related to demographics was the preponderance of younger female participants. Given that slightly more than $40 \%$ of our sample were between the ages of 18 and 29 , and nearly $60 \%$ were females, our results should be interpreted with some caution, as this is likely not representative of the wider population of potential travellers to Sicily. In fact, these demographics are likely a function of the means by which we secured our sample- - using LinkedIn and Twitter. Future research may seek to balance the number of respondents based on gender and age by intentionally oversampling older male participants. Within what is an investigation into motivational factors contributing to behavioural intentions to engage in cultural holidays, the role of gender and age may serve to explain some model relationships, especially concerning the effects of coping strategies. Younger women (who comprised a large portion of our sample) may have affected model relationships, especially as regards negative WOM and avoidance.

As differences between the consumption preferences of men and women become less distinct, it would be interesting to explore how consumers maintain the balance between the dichotomous role of masculine and feminine gender identities and understand the difference between men and women as they create gender-related self-image. In addition, gender identity closely relates to cultural change. Future research should also consider the role that other socio-demographic variables (e.g., age, income and level of education) may play in developing coping strategies. Multiple authors have highlighted the significance of gender, age, income, education, and nationality [116-119] in the model's results.

Another important limitation concerns the high percentage (67.6\%) of domestic tourists that participated in this study. Prior knowledge of particular sites would most likely shape individuals' interest in revisiting. Future researchers should seek to secure a balanced number of domestic and international tourists when examining subsequent, comparable models. As such, future research may consider undertaking a multi-group 
analysis to determine if results would hold (or be different) across these two distinct groups of travellers.

Finally, a variable that has not been included in the research model, but that could give further insight into comparable models, is destination image. According to Bigné et al. [120], Gallarza, Saura, and Garcia [121] and San Martin and Del Bosque [122], the image that a tourist has of a destination can be quite personal, as it depends on individual perceptions of the place, which can be most salient in the context of cultural tourism. Perhaps the image individuals possess of culturally rich destinations, in light of the current COVID-19 pandemic in which we find ourselves, will go far in explaining intentions to undertake a cultural tourism holiday. As we continue to embrace what travel looks like in the face of the COVID-19 pandemic (and beyond) [123], it will be of paramount importance that we continue to advance models examining various theoretically derived constructs so as to gain a timely perspective of what drives individuals' intentions to engage in this unique form of tourism [124]. For now, our work serves as a continued jumping off point, moving this line of research forward through the employment of the self-regulation theory.

Author Contributions: Conceptualization, S.P.; methodology, S.P. and M.A.R.; software, S.P. and M.A.R.; validation, S.P., M.A.R. and K.M.W.; formal analysis, S.P. and M.A.R.; investigation, S.P.; resources, S.P.; data curation, S.P.; writing—original draft preparation, S.P. and K.M.W.; writingreview and editing, S.P., M.A.R. and K.M.W.; visualization, S.P. and K.M.W.; supervision, S.P. and K.M.W.; project administration, S.P. All authors have read and agreed to the published version of the manuscript.

Funding: This work is partially financed by Portuguese Funds provided by FCT-Fundação para a Ciência e Tecnologia (Foundation for Science and Technology, Portugal) through project UIDB/04020.

Institutional Review Board Statement: Not applicable.

Informed Consent Statement: Informed consent was obtained from all subjects involved in the study.

Data Availability Statement: Should readers express interest in securing the data used in this paper, they are encouraged to contact the corresponding author.

Conflicts of Interest: The authors declare no conflict of interest.

\section{References}

1. Nguyen, T.H.H.; Cheung, C. The classification of heritage tourists: A case of Hue City, Vietnam. J. Herit. Tour. 2014, 9, 35-50. [CrossRef]

2. Kwoba, P.; Ipara, H.; Kieti, D. The connection between length of residency and local residents' attitudes towards cultural tourism development at Kogelo, Kenya. Int. J. Res. Manag. Soc. Sci. 2015, 1, 12-19.

3. Richards, G. Cultural tourism: A review of recent research and trends. J. Hosp. Tour. Manag. 2018, 36, 12-21. [CrossRef]

4. Noonan, D.S.; Rizzo, I. Economics of cultural tourism: Issues and perspectives. J. Cult. Econ. 2017, 41, 95-107. [CrossRef]

5. Barbieri, C.; Mahoney, E. Cultural tourism behaviour and preferences among the live-performing arts audience: An application of the univorous-omnivorous framework. Int. J. Tour. Res. 2010, 12, 481-496. [CrossRef]

6. Liu, Y.D. Image-based segmentation of cultural tourism market: The perceptions of Taiwan's inbound visitors. Asia Pac. J. Tour. Res. 2014, 19, 971-987. [CrossRef]

7. Csapo, J. The role and importance of cultural tourism in modern tourism industry. In Strategies for Tourism Industry-Micro and Macro Perspectives; IntechOpen: London, UK, 2012; Volume 10, pp. 201-212.

8. Alfonso, M.J.P. Cultural heritage as a tourist option. Anthropol. Horiz. 2003, 9, 97-115. [CrossRef]

9. du Cros, H.; McKercher, B. Cultural Tourism, 2nd ed.; Routledge: New York, NY, USA, 2015.

10. Espeso-Molinero, P. Trends in cultural tourism. PASOS Rev. Tur. Patrim. Cult. 2019, 17, 1101-1112.

11. López Martínez, G. El Grand Tour: Revisión de un viaje antropológico. Gran Tour 2015, 12, 106-120.

12. Smith, M.K. Issues in Cultural Tourism Studies, 3rd ed.; Routledge: New York, NY, USA, 2015.

13. Jovicic, D.Z. Key issues in the implementation of sustainable tourism. Curr. Issues Tour. 2014, 17, 297-302. [CrossRef]

14. Ashworth, G.J.; Voogd, H. Marketing of tourism places: What are we doing? J. Int. Consum. Mark. 1994, 6, 5-19. [CrossRef]

15. Jewell, B.; Crotts, J.C. Adding Psychological Value to Heritage Tourism Experiences. J. Travel Tour. Mark. 2002, 11, 13-28. [CrossRef]

16. Crompton, J.L. Motivations for pleasure vacation. Ann. Tour. Res. 1979, 6, 408-424. [CrossRef]

17. Chen, J. Tourism stakeholders attitudes toward sustainable development: A case in the Arctic. J. Retail. Consum. Serv. 2015, 22, 225-230. [CrossRef] 
18. Frochot, I.; Morrison, A.M. Benefit Segmentation: A Review of Its Applications to Travel and Tourism Research. J. Travel Tour. Mark. 2000, 9, 21-45. [CrossRef]

19. Moscardo, G.; Morrison, A.M.; Pearce, P.; Lang, C.-T.; O'Leary, J.T. Understanding vacation destination choice through travel motivation and activities. J. Vacat. Mark. 1996, 2, 109-122. [CrossRef]

20. Qiu, R.T.R.; Masiero, L.; Li, G. The psychological process of travel destination choice. J. Travel Tour. Mark. 2018, 35, 691-705. [CrossRef]

21. Sirgy, M.J.; Su, C. Destination Image, Self-Congruity, and Travel Behavior: Toward an Integrative Model. J. Travel Res. 2000, 38, 340-352. [CrossRef]

22. Wu, L.; Zhang, J.; Fujiwara, A. Representing tourists' heterogeneous choices of destination and travel party with an integrated latent class and nested logit model. Tour. Manag. 2011, 32, 1407-1413. [CrossRef]

23. Gao, J.; Zhang, Y.; Kerstetter, D.L.; Shields, S. Understanding Changes in Tourists' Use of Emotion Regulation Strategies in a Vacation Context. J. Travel Res. 2019, 58, 1088-1104. [CrossRef]

24. Koole, S.L.; Van Dillen, L.F.; Sheppes, G. The self-regulation of emotion. In Handbook of Self-Regulation: Research, Theory, and Applications; Guilford Press: New York, NY, USA, 2011; Volume 2, pp. 22-40.

25. Tyrrell, T.; Paris, C.M.; Biaett, V. A quantified triple bottom line for tourism: Experimental results. J. Travel Res. 2013, 52, 279-293. [CrossRef]

26. Woosnam, K.M.; Aleshinloye, K.D. Residents' Emotional Solidarity with Tourists: Explaining Perceived Impacts of a Cultural Heritage Festival. J. Hosp. Tour. Res. 2018, 42, 587-605. [CrossRef]

27. Woosnam, K.M.; Maruyama, N.; Boley, B.B. Perceptions of the 'Other' Residents: Implications for Attitudes of Tourism Development Focused on the Minority Ethnic Group. J. Travel Tour. Mark. 2016, 33, 567-580. [CrossRef]

28. Mowforth, M.; Munt, I. Tourism and Sustainability: Development, Globalisation and New Tourism in the Third World; Routledge: New York, NY, USA, 2015.

29. Bigne, E.; Andreu, L.; Gnoth, J. The theme park experience: An analysis of pleasure, arousal and satisfaction. Tour. Manag. 2005, 26, 833-844. [CrossRef]

30. Ene, D.; Schofield, P. An Integrated Approach to Consumer Decision Making for Budget City Breaks: The Role of Emotion. Int. J. Tour. Res. 2011, 13, 368-383. [CrossRef]

31. Prayag, G.; Hosany, S.; Odeh, K. The role of tourists' emotional experiences and satisfaction in understanding be-havioral intentions. J. Destin. Mark. Manag. 2013, 2, 118-127.

32. Prayag, G.; Hosany, S.; Muskat, B.; Del Chiappa, G. Understanding the relationships between tourists' emotional experiences, perceived overall image, satisfaction, and intention to recommend. J. Travel Res. 2017, 56, 41-54. [CrossRef]

33. Gnoth, J. Tourism motivation and expectation formation. Ann. Tour. Res. 1997, 24, 283-304. [CrossRef]

34. Goossens, C. Tourism information and pleasure motivation. Ann. Tour. Res. 2000, 27, 301-321. [CrossRef]

35. Chuang, S.-C. The Effects of Emotions on the Purchase of Tour Commodities. J. Travel Tour. Mark. 2007, 22, 1-13. [CrossRef]

36. Bagozzi, R.P.; Gopinath, M.; Nyer, P.U. The role of emotions in marketing. J. Acad. Mark. Sci. 1999, 27, 184-206. [CrossRef]

37. Mano, H.; Oliver, R.L. Assessing the Dimensionality and Structure of the Consumption Experience: Evaluation, Feeling, and Satisfaction. J. Consum. Res. 1993, 20, 451-466. [CrossRef]

38. Soscia, I. Gratitude, delight, or guilt: The role of consumers' emotions in predicting postconsumption behaviors. Psychol. Mark. 2007, 24, 871-894. [CrossRef]

39. Austin, J.T.; Vancouver, J.B. Goal constructs in psychology: Structure, process, and content. Psychol. Bull. 1996, 120, 338-375. [CrossRef]

40. Bagozzi, R.P.; Baumgartner, H.; Pieters, R.; Zeelenberg, M. The role of emotions in goal-directed behavior. In The Why of Consumption: Contemporary Perspectives on Consumer Motives, Goals, and Desires; Ratneshwar, S., Mick, D.G., Huffman, C., Eds.; Routledge: New York, NY, USA, 2000.

41. Bagozzi, R.P. Atteggiamenti Intenzioni e Comportamento: L'analisi e la Previsione dell'agire Individuale in Ambito Psico-Sociale ed Economico [Attitude Intentions and Behavior: The Analysis and Prediction of Individual Action in the Field of Psycho-Social and Economic]; Franco Angeli: Milano, Italy, 1999.

42. Ajzen, I.; Fishbein, M. Understanding Attitude and Predicting Social Behavior; Prentice-Hall: Englewood, NJ, USA, 1980.

43. Ajzen, I. Action-control: From cognition to behavior. In From Intentions to Actions: A Theory of Planned Behavior; Kuhl, J., Beckman, J., Eds.; Springer: Heidelberg, Germany, 1985; pp. 11-39.

44. Fishbein, M.; Ajzen, I. Belief, Attitude, Intention and Behaviour: An Introduction to Theory and Research; Addison-Wesley: Reading, MA, USA, 1975.

45. Ajzen, I. The theory of planned behavior. Organ. Behav. Hum. Decis. Process. 1991, 50, 179-211. [CrossRef]

46. Ajzen, I.; Driver, B.L. Application of the Theory of Planned Behavior to Leisure Choice. J. Leis. Res. 1992, 24, 207-224. [CrossRef]

47. Perugini, M.; Bagozzi, R.P. The role of desires and anticipated emotions in goal-directed behaviours: Broadening and deepening the theory of planned behaviour. Br. J. Soc. Psychol. 2001, 40, 79-98. [CrossRef]

48. Taylor, S.A. The addition of anticipated regret to attitudinally based, goal-directed models of information search be-haviours under conditions of uncertainty and risk. Br. J. Soc. Psychol. 2007, 46, 739-768. [CrossRef]

49. Bagozzi, R.P.; Dholakia, U.M. Three roles of past experience in goal setting and goal striving. In The Routines of Decision Making; Psychology Press: Hove, UK, 2014; pp. 51-68. 
50. Lazarus, R.S. Emotion and Adaptation; Oxford University Press: Oxford, UK, 1991.

51. Bagozzi, R.P. The Self-Regulation of Attitudes, Intentions, and Behavior. Soc. Psychol. Q. 1992, 55, 178. [CrossRef]

52. Carver, C.S.; Scheier, M.F. Optimism, pessimism, and self-regulation. In Optimism E Pessimism: Implications for Theory, Research, and Practice; Chang, E.C., Ed.; American Psychological Association: Washington, DC, USA, 2001; pp. 31-51.

53. Crompton, J.L.; McKay, S.L. Motives of visitors attending festival events. Ann. Tour. Res. 1997, 24, 425-439. [CrossRef]

54. Bryant, B.E.; Morrison, A.J. Travel Market Segmentation and the Implementation of Market Strategies. J. Travel Res. 1980, 18, 2-8. [CrossRef]

55. Ross, E.L.D.; Iso-Ahola, S.E. Sightseeing tourists' motivation and satisfaction. Ann. Tour. Res. 1991, 18, 226-237. [CrossRef]

56. Jamrozy, U.; Uysal, M. Travel motivation variations of overseas German visitors. In Global Tourist Behavior; Routledge: Oxfordshire, UK, 1994; Volume 6, pp. 135-160.

57. Cha, S.; McCleary, K.W.; Uysal, M. Travel Motivations of Japanese Overseas Travelers: A Factor-Cluster Segmentation Approach. J. Travel Res. 1995, 34, 33-39. [CrossRef]

58. Deci, E.; Ryan, R.M. The general causality orientations scale: Self-determination in personality. J. Res. Pers. 1985, 19, 109-134. [CrossRef]

59. Ryan, R.M.; Deci, E.L. Intrinsic and extrinsic motivations: Classic definitions and new directions. Contemp. Educ. Psychol. 2000, 25, 54-67. [CrossRef] [PubMed]

60. Na-Nan, K.; Sanamthong, E.; Sulong, M. Employees engagement, quality of service and customers' satisfaction affecting customer loyalty of hair and beauty salon business. Int. J. Appl. Bus. Econ. Res. 2015, 13, 3409-3421.

61. Bigné, J.E.; Andreu, L. Emotions in segmentation: An empirical study. Ann. Tour. Res. 2004, 31, 682-696. [CrossRef]

62. Hosany, S. Appraisal Determinants of Tourist Emotional Responses. J. Travel Res. 2012, 51, 303-314. [CrossRef]

63. Pestana, M.H.; Parreira, A.; Moutinho, L. Motivations, emotions and satisfaction: The keys to a tourism destination choice. J. Destin. Mark. Manag. 2020, 16, 100332. [CrossRef]

64. Breitsohl, J.; Garrod, B. Assessing tourists' cognitive, emotional and behavioural reactions to an unethical destination incident. Tour. Manag. 2016, 54, 209-220. [CrossRef]

65. Chan, D.W. Emotional intelligence, self-efficacy, and coping among Chinese prospective and in-service teachers in Hong Kong. Educ. Psychol. 2008, 28, 397-408. [CrossRef]

66. Duhachek, A.; Oakley, J.L. Mapping the hierarchical structure of coping: Unifying empirical and theoretical perspectives. J. Consum. Psychol. 2007, 17, 216-233. [CrossRef]

67. Jin, Y.; Hong, S.Y. Explicating crisis coping in crisis communication. Public Relat. Rev. 2010, 36, 352-360. [CrossRef]

68. Smith, R.E.; Vogt, C.A. The Effects of Integrating Advertising and Negative Word-of-Mouth Communications on Message Processing and Response. J. Consum. Psychol. 1995, 4, 133-151. [CrossRef]

69. Ward, J.C.; Ostrom, A.L. Complaining to the Masses: The Role of Protest Framing in Customer-Created Complaint Web Sites. J. Consum. Res. 2006, 33, 220-230. [CrossRef]

70. Grappi, S.; Romani, S.; Bagozzi, R.P. Consumer response to corporate irresponsible behavior: Moral emotions and virtues. J. Bus. Res. 2013, 66, 1814-1821. [CrossRef]

71. Daugherty, T.; Hoffman, E. eWOM and the importance of capturing consumer attention within social media. J. Mark. Commun. 2014, 20, 82-102. [CrossRef]

72. Pourfakhimi, S.; Duncan, T.; Coetzee, W. Electronic word of mouth in tourism and hospitality consumer behaviour: State of the art. Tour. Rev. 2020, 75, 637-661. [CrossRef]

73. UNESCO. Italy. 2021. Available online: http://whc.unesco.org/en/statesparties/IT (accessed on 22 July 2021).

74. ISTAT. National Institute of Statistics, Italy. 2021. Available online: https:/ / knoema.com/atlas/sources /ISTAT?topic=Social@ionId=IT (accessed on 22 July 2021).

75. Nunkoo, R.; Ribeiro, M.A.; Sunnassee, V.; Gursoy, D. Public trust in mega event planning institutions: The role of knowledge, transparency and corruption. Tour. Manag. 2018, 66, 155-166. [CrossRef]

76. Simons, H.W. Persuasion; Addison-Wesley: Reading, UK, 1976.

77. Osgood, E.C.; Suci, J.G.; Tannenbaum, H.P. The Measurement of Meaning; University of Illinois Press: Champaign, IL, USA, 1975.

78. Broadhead-Fearn, D.; White, K.M. The Role of Self-Efficacy in Predicting Rule-Following Behaviors in Shelters for Homeless Youth: A Test of the Theory of Planned Behavior. J. Soc. Psychol. 2006, 146, 307-325. [CrossRef]

79. Lazarus, R.S.; Launier, R. Stress-related transactions between person and environment. In Perspectives in Interactional Psychology; Springer: Boston, MA, USA, 1978; pp. 287-327.

80. Lazarus, R.S.; Averill, J.R.; Opton, E.M. The psychology of coping: Issues of research and assessment. In Coping and Adaptation; Basic Books: New York, NY, USA, 1974; pp. 249-315.

81. Kimmel, A.J.; Audrain-Pontevia, A.-F. Analysis of commercial rumors from the perspective of marketing managers: Rumor prevalence, effects, and control tactics. J. Mark. Commun. 2010, 16, 239-253. [CrossRef]

82. Higgins, E.; Rholes, W.S. "Saying is believing": Effects of message modification on memory and liking for the person described. J. Exp. Soc. Psychol. 1978, 14, 363-378. [CrossRef]

83. Kim, J.; Naylor, G.; Sivadas, E.; Sugumaran, V. The unrealized value of incentivized eWOM recommendations. Mark. Lett. 2016, 27, 411-421. [CrossRef] 
84. Nyer, P.U.; Gopinath, M. Effects of complaining versus negative word of mouth on subsequent changes in satisfac-tion: The role of public commitment. Psychol. Mark. 2005, 22, 937-953. [CrossRef]

85. He, H.; Harris, L. Moral disengagement of hotel guest negative WOM: Moral identity centrality, moral awareness, and anger. Ann. Tour. Res. 2014, 45, 132-151. [CrossRef]

86. Folkman, S.; Lazarus, R.S.; Dunkel-Schetter, C.; DeLongis, A.; Gruen, R.J. Dynamics of a stressful encounter: Cognitive appraisal, coping, and encounter outcomes. J. Pers. Soc. Psychol. 1986, 50, 992-1003. [CrossRef]

87. Folkman, S.; Lazarus, R.S. Coping as a mediator of emotion. J. Pers. Soc. Psychol. 1988, 54, 466-475. [CrossRef]

88. Abougomaah, N.H.; Schlacter, J.L.; Gaidis, W. Elimination and choice phases in evoked set formation. J. Consum. Mark. 1987, 4, 67-72. [CrossRef]

89. Byrne, B.M. Structural Equation Modeling With AMOS, EQS, and LISREL: Comparative Approaches to Testing for the Factorial Validity of a Measuring Instrument. Int. J. Test. 2001, 1, 55-86. [CrossRef]

90. Geiser, C.; Bishop, J.; Lockhart, G.; Shiffman, S.; Grenard, J.L. Analyzing latent state-trait and multiple-indicator latent growth curve models as multilevel structural equation models. Front. Psychol. 2013, 4, 975. [CrossRef]

91. Kline, R.B. Principles and Practice of Structural Equation Modeling; Guilford Publications: New York, NY, USA, 2015.

92. Hu, L.; Bentler, P.M. Cutoff criteria for fit indexes in covariance structure analysis: Conventional criteria versus new alternatives. Struct. Equ. Model. A Multidiscip. J. 1999, 6, 1-55. [CrossRef]

93. Browne, M.W.; Cudeck, R. Alternative Ways of Assessing Model Fit. Sociol. Methods Res. 1992, 21, 230-258. [CrossRef]

94. Arbuckle, J.L.; Wothke, W. Amos 4.0 User's Guide; Marketing Department, SPSS Inc.: Chicago, IL, USA, 1999.

95. Shrout, P.E.; Bolger, N. Mediation in experimental and nonexperimental studies: New procedures and recommendations. Psychol. Methods 2002, 7, 422. [CrossRef] [PubMed]

96. Tabachnick, B.G.; Fidell, L.S.; Ullman, J.B. Using Multivariate Statistics, 5th ed.; Pearson: Boston, MA, USA, 2007.

97. Malhotra, N.K.; Kim, S.S.; Patil, A. Common method variance in IS research: A comparison of alternative approaches and a reanalysis of past research. Manag. Sci. 2006, 52, 1865-1883. [CrossRef]

98. Hair, J.; Black, W.C.; Babin, B.; Anderson, R. Multivariate Data Analysis, 8th ed.; Cengage: Boston, MA, USA, 2019.

99. Anderson, J.C.; Gerbing, D.W. Structural equation modeling in practice: A review and recommended two-step approach. Psychol. Bull. 1988, 103, 411-423. [CrossRef]

100. Soper, D.S. Post-Hoc Statistical Power Calculator for Multiple Regression [Software]. 2021. Available online: https://www. danielsoper.com/statcalc (accessed on 22 July 2021).

101. Savalei, V.; Bentler, P.M. Structural equation modeling. The Handbook of Marketing Research: Uses, Misuses, and Future Advances; Sage: Newcastle-upon-Tyne, UK, 2006; pp. 330-364.

102. Bollen, K.A. Structural Equations with Latent Variables; John Wiley \& Sons: Hoboken, NJ, USA, 1989 ; Volume 210.

103. Chen, J.L.; Hung, C.H. The indirect effect in multiple mediators model by structural equation modeling. Eur. J. Bus. Econ. Account. 2016, 4, 36-43.

104. Preacher, K.J.; Hayes, A. Asymptotic and resampling strategies for assessing and comparing indirect effects in multiple mediator models. Behav. Res. Methods 2008, 40, 879-891. [CrossRef]

105. Song, J.H.; Lee, C.-K.; Kan, S.K.; Boo, S.-J. The effect of environmentally friendly perceptions on festival visitors' de-cision-making process using an extended model of goal-directed behavior. Tour. Manag. 2012, 33, 1417-1428. [CrossRef]

106. Song, H.; Lee, C.-K.; Reisinger, Y.; Xu, H.-L. The role of visa exemption in Chinese tourists' decision-making: A model of goal-directed behavior. J. Travel Tour. Mark. 2017, 34, 666-679. [CrossRef]

107. Conner, M.; Abraham, C. Conscientiousness and the Theory of Planned Behavior: Toward a more Complete Model of the Antecedents of Intentions and Behavior. Pers. Soc. Psychol. Bull. 2001, 27, 1547-1561. [CrossRef]

108. Oh, H.; Hsu, C. Volitional degrees of gambling behaviors. Ann. Tour. Res. 2001, 28, 618-637. [CrossRef]

109. Bagozzi, R.P.; Edwards, J. A General Approach for Representing Constructs in Organizational Research. Organ. Res. Methods 1998, 1, 45-87. [CrossRef]

110. Gleicher, F.; Boninger, D.S.; Strathman, A.; Armor, D.; Hetts, J.; Ahn, M. With an eye toward the future: The impact of counterfactual thinking on affect, attitudes, and behaviour. In What Might Have Been: The Social Psychology of Counterfactual Thinking; Roese, N.J., Olson, J.M., Eds.; Erlbaum: Mahwah, NJ, USA, 1995; pp. 283-304.

111. Perugini, M.; Bagozzi, B.P. An alternative view of pre-volitional processes in decision making: Conceptual issues and empirical evidence. In Contemporary Perspectives on the Psychology of Attitudes: The Cardiff Symposium; Haddock, G., Maio, G.R., Eds.; Psychology Press: Hove, UK, 2004; pp. 169-201.

112. Bagozzi, R.P.; Dholakia, U.M. Antecedents and purchase consequences of customer participation in small group brand communities. Int. J. Res. Mark. 2006, 23, 45-61. [CrossRef]

113. Taylor, A.S.; Ishida, C.; Wallace, D.W. Intention to engage in digital piracy: A conceptual model and empirical test. J. Serv. Res. 2009, 11, 246-262. [CrossRef]

114. Saunders, M.; Lewis, P.; Thornhill, A. Research Methods for Business Students, 6th ed.; Pearson Education Limited: London, UK, 2012.

115. Teddlie, C.; Yu, F. Mixed methods sampling. J. Mix. Methods Res. 2007, 1, 77-100. [CrossRef]

116. Baloglu, S. Image variations of Turkey by familiarity index: Informational and experiential dimensions. Tour. Manag. 2001, 22, 127-133. [CrossRef]

117. MacKay, K.J.; Fesenmaier, D.R. Pictorial element of destination in image formation. Ann. Tour. Res. 1997, 24, 537-565. [CrossRef] 
118. Tasci, A.D.A. Assessment of destination image determinants using a multiple regression model. Tour. Rev. 2007, 62, 23-30. [CrossRef]

119. Tasci, A.A.D.; Khalilzadeh, J.; Uysal, M. Network analysis of the caucasus' image. Curr. Issues Tour. 2017, 22, 827-852. [CrossRef]

120. Bigne, E.J.; Sanchez, M.I.; Sanchez, J. Tourism image, evaluation variables and after purchase behaviour: Inter-relationship. Tour. Manag. 2001, 22, 607-616. [CrossRef]

121. Gallarza, G.M.; Saura, I.G.; Garcia, H.C. Destination image: Towards a conceptual framework. Ann. Tour. Res. 2002, 29, 56-78. [CrossRef]

122. San Martın Gutierrez, H.; Rodriguez del Bosque, I. Un enfoque de gestion de la imagen de marca de los destinos turısticos basado en las caracteristicas del turista. Rev. Anal. Tur. 2011, 9, 5-13.

123. Joo, D.; Xu, W.; Lee, J.; Lee, C.-K.; Woosnam, K.M. Residents' perceived risk, emotional solidarity, and support for tourism amidst the COVID-19 pandemic. J. Destin. Mark. Manag. 2021, 19, 100553. [CrossRef]

124. Megeirhi, H.A.; Woosnam, K.M.; Ribeiro, M.A.; Ramkissoone, H.R.; Denley, T.J. Employing a value-belief-norm framework to gauge Carthage residents' intentions to support sustainable cultural heritage tourism. J. Sustain. Tour. 2020, 28, 1351-1370. [CrossRef] 